\title{
SISTEM PENDUKUNG KEPUTUSAN PEMBAYARAN BEASISWA DENGAN MENGGUNAKAN METODE WEIGHTED PRODUCT (WP)
}

\author{
Evasaria M. Sipayung, Yosi Yonata, Chrevita J. E. Rende \\ Departemen Sistem Informasi, Institut Teknologi Harapan Bangsa, Bandung \\ E-mail: evasaria@ithb.ac.id
}

\begin{abstract}
Anak Pelangi Indonesia (API) Foundation is a non-profit foundation that offers scholarship programs for elementary, middle and high school students. This institute is supported by donaturs who give contribution to the Foundation. The donation is processed to be a cost that is used to pay Sumbangan Pembinaan Pendidikan (SPP) or Education Development Donation of each student. Currently, the provision of monthly donor fund is at uncertain amount so that the Foundation needs to determine the students of whom SPP will be firstly paid. However, the funding needs of each student are different due to the different amount of SPP and a giving fine from the school for the tardiness in paying the tuition. From these matters, the Foundation finds it difficult in deciding which students whose the tuition will be paid first. The solution to this problem is to use the four criteria referring to the tuition payment, namely the difference of pay date, fine, rank, and the amount of payment. The four criteria is then given the same integrity which is $25 \%$ for each criteria and counted by using Weighted Product (WP) method. The result of this research is an information system to the selection of scholarship payment using Weight Product method that takes the biggest value from the calculation result as a reference in deciding which students of whom SPP will be initially paid in accordance with the current fund condition
\end{abstract}

Keywords: scholarship, SPP, Weighted Product

\begin{abstract}
Abstrak
Yayasan Anak Pelangi Indonesia membuka program beasiswa untuk siswa SD, SMP dan SMA. Yayasan ini didukung oleh donatur yang memberikan sumbangan dana yang kemudian akan digunakan untuk biaya pembayaran Sumbangan Pembinaan Pendidikan (SPP). Saat ini jumlah donasi yang diberikan oleh donatur tidak pasti jumlahnya sehingga terjadi kekurangan dana pada Yayasan sedangkan kebutuhan dana dari setiap anak berbedabeda. Jumlah SPP setiap siswa berbeda dan pemberian denda kepada siswa yang terlambat membayar SPP. Hal tersebut membuat Yayasan kesulitan dalam menentukan siswa yang akan dibayar terlebih dahulu. Pemecahan masalah adalah dengan menggunakan metode Weighted Product (WP) dan menghitung kriteria yang menjadi acuan dalam pembayaran SPP. Hasil akhir dari sistem adalah melakukan seleksi pembayaran beasiswa sehingga didapat siswa yang akan dibayar terlebih dahulu sesuai dengan dana yang ada saat ini
\end{abstract}

Kata Kunci: beasiswa, SPP, Weighted Product

\section{Pendahuluan}

Yayasan Anak Pelangi Indonesia (API) adalah suatu Yayasan (non-profit) yang dibawahi oleh Gereja El Shaddai Injili Sepenuh-El Shaddai Creative Community (GEIS-ECC). Yayasan ini bergerak di bidang pendidikan yaitu membuka program beasiswa untuk siswa SD, SMP dan SMA yang orang tuanya tidak mampu membayar uang sekolah. Program beasiswa dari Yayasan ini bekerja sama dengan 53 sekolah (SD, SMP, SMA) yang ada di Kota Bandung. Yayasan ini juga didukung oleh donator-donatur yang memberikan sumbangan dana bagi Yayasan. Sumbangan dana tersebut kemudian akan diproses menjadi biaya yang digunakan untuk membayar uang sekolah. Terdapat dua kategori donatur yang memberikan sumbangan dana bagi Yayasan yaitu donatur tetap dan donatur tidak tetap. Donatur tetap memberikan dana setiap bulannya namun 
jumlahnya tidak pasti sedangkan untuk donatur tidak tetap memberikan dan sesuai dengan keinginan mereka sendiri, hal itu membuat dana pemasukan Yayasan setiap bulan menjadi tidak pasti sehingga terjadi kekurangan dana untuk pembayaran Sumbangan Pembinaan Pendidikan (SPP).

Keterbatasan dana tersebut membuat Yayasan harus menentukan siapa siswa yang akan didahulukan dalam pembayaran SPP. Tahun 2014, Yayasan memberikan beasiswa kepada 59 orang anak, 59 orang anak tersebut mempunyai kebutuhan dana berbeda-beda setiap bulan contohnya jumlah SPP dari setiap siswa berbedabeda dan jika ada siswa yang terlambat membayar SPP maka siswa tersebut akan dikenakan denda sehingga membuat jumlah yang akan dibayar menjadi lebih besar. Dalam pembayaran SPP, Yayasan mendahulukan siswa yang berjenis beasiswa Diakonia, jika terdapat uang sisa dari pembayaran beasiswa jenis Diakonia maka uang tersebut akan dibayarkan untuk siswa berjenis beasiswa Misi. Admin hanya memilih beberapa siswa yang dibayarkan untuk beasiswa misi, sesuai dengan sisa dana yang ada pada Yayasan. Pada tahun 2013, pernah terjadi beberapa keterlambatan (5-6 kali) dalam setahun untuk 10 lebih siswa. Keterlambatan tersebut membuat beberapa siswa dikenakan denda karena terlambat melakukan pembayaran. Hal ini disebabkan dana yang diterima tidak mencukupi untuk membayarkan keseluruhan beasiswa. Keterlambatan pembayaran ini mengakibatkan ada beberapa siswa tidak bisa mengikuti Ujian Tengah Semester (UTS).

\section{Metode Weighted Product (WP)}

Menurut Kusmarini, Sri dkk 2006, metode Weighted Product menggunakan teknik perkalian untuk menghubungkan rating atribut, dimana rating tiap atribut harus dipangkatkan terlebih dahulu dengan bobot atribut yang bersangkutan. Proses ini sama halnya dengan proses normalisasi. Preferensi untuk alternatif $A_{i}$ diberikan sebagai berikut:

$\boldsymbol{S i}=\prod_{j=1}^{\boldsymbol{n}} \boldsymbol{X} \boldsymbol{i} \boldsymbol{j}^{\boldsymbol{W j}} ; \mathrm{i}=1,2, . ., \mathrm{m}$

dimana:

$S$ menyatakan preferensi alternatif

$X$ menyatakan nilai kriteria

$W$ menyatakan bobot kriteria

$i$ menyatakan alternatif

$j$ menyatakan kriteria

$n$ menyatakan banyaknya kriteria $\sum_{j=1}^{n} W j=1$

$W j$ dalah pangkat bernilai positif untuk atribut keuntungan, dan bernilai negative untuk atribut biaya.

Preferensi relatif dari setiap alternatif diberikan sebagai berikut:

$V i=\frac{\prod_{j=1}^{n} X i j^{W j}}{\prod_{j=1}^{n}(X j)^{W j}} ; i=1,2, \ldots, m$

dimana:

$V$ menyatakan preferensi alternatif

$X$ menyatakan nilai kriteria

$W$ menyatakan bobot kriteria

$i$ menyatakan alternatif

$j$ menyatakan kriteria

$n$ menyatakan banyaknya kriteria

\section{Analisis Masalah}

Yayasan Anak Pelangi Indonesia (API) adalah suatu Yayasan (non-profit), Yayasan ini bergerak di bidang pendidikan yaitu membuka sekolah untuk anak-anak dan membuka program beasiswa. Beasiswa diberikan untuk siswa Sekolah Dasar (SD), Sekolah Menengah Pertama (SMP) dan Sekolah Menengah Atas (SMA) yang orang tuanya tidak mampu membayar uang sekolah. Saat ini Yayasan API memberikan 2 jenis beasiswa yaitu beasiswa Misi dan Diakonia. Beasiswa jenis Misi, Yayasan tidak membayar uang sekolah sepenuhnya namun membayar $\mathrm{Rp}$ 100.000. Sedangkan beasiswa jenis diakonia, Yayasan akan membayar penuh uang sekolah dari anak yang bersangkutan. Yayasan ini juga didukung oleh donator-donatur yang memberikan sumbangan dana bagi Yayasan. Sumbangan dana tersebut kemudian akan diproses menjadi biaya yang digunakan untuk membayar uang sekolah. Terdapat dua kategori donatur yang memberikan sumbangan dana bagi Yayasan yaitu donatur tetap dan donatur tidak tetap. Donatur tetap memberikan dana setiap bulannya namun jumlahnya tidak pasti. Sedangkan donatur tidak tetap memberikan dana sesuai dengan keinginan mereka sendiri. Hal itu membuat dana pemasukan Yayasan setiap bulan menjadi tidak pasti sehingga terjadi kekurangan dana untuk pembayaran Sumbangan Pembinaan Pendidikan (SPP). Keterbatasan dana tersebut membuat Yayasan harus menentukan siapa siswa yang akan didahulukan dalam pembayaran SPP. Pada tahun 2014, Yayasan memberikan beasiswa kepada 59 orang anak. Keseluruhan anak tersebut mempunyai kebutuhan dana berbeda-beda setiap bulan. Jumlah SPP dari setiap siswa berbeda-beda 
dan jika ada siswa yang terlambat membayar SPP maka siswa tersebut akan dikenakan denda sehingga membuat jumlah yang akan dibayar menjadi lebih besar Saat ini dalam menentukan pembayaran beasiswa yayasan menggunakan 4 penentu sebagai acuan dalam pembayar beasiswa, terdiri dari: jumlah pembayaran, selisih tanggal pembayaran, denda, dan peringkat. Jumlah kebutuhan dana SPP yang berbeda-beda serta penentu pembayaran yang tidak pasti membuat yayasan kesulitan dalam menentukan siswa yang akan dibayar terlebih dahulu sesuai dengan keadaan dana pada Yayasan. Untuk itu diperlukan suatu metode yang dapat menyeleksi siswa-siswa sehingga dapat menentukan siswa yang akan dibayar terlebih dahulu.

\section{Analisis Metode Weighted Product}

Berdasarkan algoritma metode Weighted Product, maka

a. Alternatif dalam penelitian ini terdiri dari 37 siswa

b. Terdapat 4 kriteria penentu yang menjadi acuan yaitu selisih pembayaran, jumlah pembayaran, denda dan peringkat. Tabel 1 merupakan penjelasan dari keempat kriteria yang digunakan.

\begin{tabular}{|c|c|c|}
\hline Notasi & Kriteria & Keterangan \\
\hline $\mathrm{C} 1$ & $\begin{array}{l}\text { Selisih } \\
\text { Tanggal } \\
\text { Bayar }\end{array}$ & $\begin{array}{l}\text { Selisih tanggal bayar diambil } \\
\text { antara tanggal } 1 \text { setiap bulan } \\
\text { dengan tanggal jatuh tempo } \\
\text { pembayaran SPP. } \\
\text { Semakin dekat (rendah) tanggal } \\
\text { pembayaran SPP maka semakin } \\
\text { tinggi pengaruhnya pada } \\
\text { pembayaran SPP. }\end{array}$ \\
\hline $\mathrm{C} 2$ & $\begin{array}{l}\text { Jumlah } \\
\text { Bayar }\end{array}$ & $\begin{array}{l}\text { Kriteria ini dihitung } \\
\text { berdasarkan jumlah yang akan } \\
\text { dibayarkan setiap siswa } \\
\text { Semakin rendah jumlah bayar, } \\
\text { maka semakin tinggi } \\
\text { pengaruhnya pada pembayaran } \\
\text { SPP. } \\
\text { Jumlah biaya per siswa yang } \\
\text { dibayarkan terdiri dari } 80.000 \text {, } \\
100.000 \text {, dan } 350.000\end{array}$ \\
\hline $\mathrm{C} 3$ & Denda & $\begin{array}{l}\text { Kriteria ini dihitung jika siswa } \\
\text { yang bersangkutan dikenakan } \\
\text { denda. } \\
\text { Semakin tinggi dendanya, maka } \\
\text { semakin berpengaruh pada } \\
\text { pembayaran SPP. } \\
\text { Denda terdiri dari } 50.000 \text {, } \\
45.000 \text {, dan } 25.000 \text {. Jumlah } \\
\text { bayar didapat dari data-data } \\
\text { yang ada Pada kriteria denda, } \\
\text { siswa yang tidak mempunyai } \\
\text { denda diberi angka } 1 \\
\text { dikarenakan jika diberi angka } 0 \\
\text { pada perhitungan akan sangat } \\
\text { berpengaruh pada proses } \\
\text { perkalian dan hasilnya tidak }\end{array}$ \\
\hline
\end{tabular}

\begin{tabular}{|c|c|c|}
\hline Notasi & Kriteria & Keterangan \\
\hline & & $\begin{array}{l}\text { akan maksimal untuk itu diberi } \\
\text { angka } 1 \text { untuk menangani nilai } \\
0 \text { tersebut. }\end{array}$ \\
\hline $\mathrm{C} 4$ & $\begin{array}{l}\text { Prestasi/ } \\
\text { Peringkat }\end{array}$ & $\begin{array}{l}\text { O Kriteria ini diambil berdasarkan } \\
\text { nilai raport dari setiap siswa. } \\
\text { Semakin rendah nilai } \\
\text { prestasinya, maka semakin } \\
\text { tinggi pengaruhnya pada } \\
\text { pembayaran SPP. } \\
\text { Siswa yang tidak mempunyai } \\
\text { rangking diberi angka 100, } \\
\text { karena jika diberi angka } 0 \text { juga } \\
\text { akan berpengaruh pada proses } \\
\text { perkalian }\end{array}$ \\
\hline
\end{tabular}

Dari 4 kriteria dibuat rating kecocokan dari setiap alternatif pada kriteria. Bobot masing-masing kriteria adalah sebesar 0.25 .

Tabel 2 Alternatif pada Kriteria

\begin{tabular}{|c|c|c|c|c|c|}
\hline \multirow{2}{*}{ No } & \multirow{2}{*}{ Alternatif } & \multicolumn{4}{|c|}{ Kriteria } \\
\hline & & C1 & $\mathrm{C} 2$ & C3 & $\mathrm{C} 4$ \\
\hline 1 & Siswa_1 & 2 & 100000 & 1 & 1 \\
\hline 2 & Siswa_2 & 3 & 100000 & 1 & 5 \\
\hline 3 & Siswa_3 & 4 & 100000 & 1 & 3 \\
\hline 4 & Siswa_4 & 2 & 100000 & 1 & 9 \\
\hline 5 & Siswa_5 & 4 & 100000 & 1 & 10 \\
\hline 6 & Siswa_6 & 3 & 100000 & 1 & 10 \\
\hline 7 & Siswa_7 & 5 & 350000 & 25000 & 5 \\
\hline 8 & Siswa_8 & 3 & 100000 & 25000 & 100 \\
\hline 9 & Siswa_9 & 2 & 80000 & 25000 & 100 \\
\hline 10 & Siswa_10 & 1 & 350000 & 25000 & 100 \\
\hline 11 & Siswa_11 & 4 & 350000 & 25000 & 100 \\
\hline 12 & Siswa_12 & 2 & 350000 & 1 & 100 \\
\hline 13 & Siswa_13 & 2 & 350000 & 1 & 100 \\
\hline 14 & Siswa_14 & 3 & 350000 & 1 & 6 \\
\hline 15 & Siswa_15 & 1 & 350000 & 1 & 4 \\
\hline 16 & Siswa_16 & 3 & 350000 & 1 & 3 \\
\hline 17 & Siswa_17 & 4 & 350000 & 1 & 2 \\
\hline 18 & Siswa_18 & 2 & 350000 & 1 & 100 \\
\hline 19 & Siswa_19 & 1 & 100000 & 25000 & 100 \\
\hline 20 & Siswa_20 & 4 & 100000 & 1 & 100 \\
\hline 21 & Siswa_21 & 1 & 100000 & 25000 & 100 \\
\hline 22 & Siswa_22 & 3 & 100000 & 25000 & 100 \\
\hline 23 & Siswa_23 & 8 & 100000 & 45000 & 100 \\
\hline 24 & Siswa_24 & 6 & 100000 & 50000 & 100 \\
\hline 25 & Siswa_25 & 8 & 80000 & 1 & 100 \\
\hline
\end{tabular}




\begin{tabular}{r|l|r|r|r|r}
\hline \multirow{2}{*}{ No } & \multirow{2}{*}{ Alternatif } & \multicolumn{4}{|c}{ Kriteria } \\
\cline { 3 - 6 } & & C1 & \multicolumn{1}{c|}{ C2 } & \multicolumn{1}{c}{ C3 } & \multicolumn{1}{c}{ C4 } \\
\hline 26 & Siswa_26 & 7 & 100000 & 1 & 100 \\
\hline 27 & Siswa_27 & 6 & 100000 & 1 & 100 \\
\hline 28 & Siswa_28 & 3 & 100000 & 1 & 6 \\
\hline 29 & Siswa_29 & 6 & 100000 & 1 & 1 \\
\hline 30 & Siswa_30 & 3 & 100000 & 1 & 2 \\
\hline 31 & Siswa_31 & 2 & 100000 & 1 & 3 \\
\hline 32 & Siswa_32 & 5 & 100000 & 1 & 1 \\
\hline 33 & Siswa_33 & 7 & 100000 & 25000 & 9 \\
\hline 34 & Siswa_34 & 2 & 100000 & 1 & 100 \\
\hline 35 & Siswa_35 & 1 & 100000 & 25000 & 100 \\
\hline 36 & Siswa_36 & 1 & 100000 & 25000 & 7 \\
\hline 37 & Siswa_37 & 6 & 100000 & 25000 & 8 \\
\hline
\end{tabular}

c. Menentukan nilai vektor $\mathrm{S}$, menghitung dengan rumus persamaan (1). Nilai vector $\mathrm{S}$ dihitung berdasarkan nilai kriteria yang ada di tabel 2. Tabel 3 contoh hasil perhitungan nilai $\mathrm{S}$ untuk alternatif 1-7.

Tabel 3 Contoh Hasil Perhitungan Vektor S

\begin{tabular}{c|c|c}
\hline Vektor & \multicolumn{1}{|c|}{ Perkalian Bobot } & Nilai S \\
\hline S1 & $\left(2^{-0.25}\right)\left(100000^{0.25}\right)\left(1^{-0.25}\right)\left(1^{-0.25}\right)$ & 0.047287 \\
\hline S2 & $\left(3^{-0.25}\right)\left(100000^{0.25}\right)\left(1^{-0.25}\right)\left(5^{-0.25}\right)$ & 0.028574 \\
\hline S3 & $\left(4^{-0.25}\right)\left(100000^{0.25}\right)\left(1^{-0.25}\right)\left(3^{-0.25}\right)$ & 0.030214 \\
\hline S4 & $\left(2^{-0.25}\right)\left(100000^{0.25}\right)\left(1^{-0.25}\right)\left(9^{-0.25}\right)$ & 0.027301 \\
\hline S5 & $\left(4^{-0.25}\right)\left(100000^{0.25}\right)\left(1^{-0.25}\right)\left(10^{-0.25}\right)$ & 0.022361 \\
\hline S6 & $\left(3^{-0.25}\right)\left(100000^{0.25}\right)\left(1^{-0.25}\right)\left(10^{-0.25}\right)$ & 0.028574 \\
\hline S7 & $\begin{array}{l}\left(^{-0.25}\right)\left(350000^{0.25}\right)\left(25000^{-0.25}\right)\left(5^{-}\right. \\
0.25\end{array}$ & 0.109327 \\
\hline & \multicolumn{2}{|l}{}
\end{tabular}

d. Menentukan vektor $\mathrm{V}$, menghitung dengan rumus persamaan (3). Nilai $S$ pada tabel dihitung nilai $\mathrm{V}$. Tabel 4 contoh hasil perhitungan nilai $\mathrm{V}$ untuk alternative 1-7.

Tabel 4 Contoh Hasil Perhitungan Vektor V

\begin{tabular}{c|c|c}
\hline Vektor & Perhitungan & Hasil \\
\hline V1 & $0.047287 / 3.42687$ & 0.013799 \\
\hline V2 & $0.028574 / 3.42687$ & 0.008338 \\
\hline V3 & $0.030214 / 3.42687$ & 0.008817 \\
\hline V4 & $0.027301 / 3.42687$ & 0.007967 \\
\hline V5 & $0.022361 / 3.42687$ & 0.006525 \\
\hline V6 & $0.028574 / 3.42687$ & 0.008338 \\
\hline
\end{tabular}

\begin{tabular}{c|c|c}
\hline Vektor & Perhitungan & Hasil \\
\hline V7 & $0.109327 / 3.42687$ & 0.031903 \\
\hline
\end{tabular}

e. Menemukan urutan alternatif terbaik yang akan menjadi keputusan dengan mengurutkan hasil perhitungan dari nilai vektor V. Dari hasil perhitungan vector $\mathrm{V}$ untuk semua alternatif kemudian diurutkan dari nilai $\mathrm{V}$ terbesar sampai terkecil.

Tabel 5 Hasil Vektor V yang sudah diurutkan

\begin{tabular}{|c|c|c|c|}
\hline No & Alternatif & Nilai $\mathbf{V}$ & Jumlah Bayar \\
\hline 1 & Siswa_36 & 0.12686 & 100.000 \\
\hline 2 & Siswa_37 & 0.07839 & 100.000 \\
\hline 3 & Siswa_33 & 0.07324 & 100.000 \\
\hline 4 & Siswa_19 & 0.06525 & 100.000 \\
\hline 5 & Siswa_21 & 0.06525 & 100.000 \\
\hline 6 & Siswa_35 & 0.06525 & 100.000 \\
\hline 7 & Siswa_9 & 0.05802 & 80.000 \\
\hline 8 & Siswa_8 & 0.04958 & 100.000 \\
\hline 9 & Siswa_22 & 0.04958 & 100.000 \\
\hline 10 & Siswa_24 & 0.04958 & 100.000 \\
\hline 11 & Siswa_10 & 0.04771 & 350.000 \\
\hline 12 & Siswa_23 & 0.04494 & 100.000 \\
\hline 13 & Siswa_11 & 0.03373 & 350.000 \\
\hline 14 & Siswa_7 & 0.03190 & 350.000 \\
\hline 15 & Siswa_1 & 0.01380 & 100.000 \\
\hline 16 & Siswa_32 & 0.01097 & 100.000 \\
\hline 17 & Siswa_29 & 0.01049 & 100.000 \\
\hline 18 & Siswa_30 & 0.01049 & 100.000 \\
\hline 19 & Siswa_31 & 0.01049 & 100.000 \\
\hline 20 & Siswa_15 & 0.00912 & 350.000 \\
\hline 21 & Siswa_3 & 0.00882 & 100.000 \\
\hline 22 & Siswa_2 & 0.00834 & 100.000 \\
\hline 23 & Siswa_6 & 0.00834 & 100.000 \\
\hline 24 & Siswa_4 & 0.00797 & 100.000 \\
\hline 25 & Siswa_28 & 0.00797 & 100.000 \\
\hline 26 & Siswa_16 & 0.00767 & 350.000 \\
\hline 27 & Siswa_5 & 0.00653 & 100.000 \\
\hline 28 & Siswa_13 & 0.00645 & 350.000 \\
\hline 29 & Siswa_14 & 0.00645 & 350.000 \\
\hline 30 & Siswa_34 & 0.00436 & 100.000 \\
\hline 31 & Siswa_20 & 0.00367 & 100.000 \\
\hline
\end{tabular}




\begin{tabular}{r|l|r|r}
\hline No & Alternatif & Nilai V & Jumlah Bayar \\
\hline 32 & Siswa_27 & 0.00332 & 100.000 \\
\hline 33 & Siswa_25 & 0.00326 & 80.000 \\
\hline 34 & Siswa_12 & 0.00319 & 350.000 \\
\hline 35 & Siswa_18 & 0.00319 & 350.000 \\
\hline 36 & Siswa_26 & 0.00319 & 100.000 \\
\hline 37 & Siswa_17 & 0.00268 & 350.000 \\
\hline \multicolumn{3}{|c}{ Total } & 6.160 .000 \\
\hline
\end{tabular}

Dari Tabel 5 didapatkan bahwa dana yang dibutuhkan untuk membayar semua SPP untuk 37 siswa sebesar Rp 6.160.000. Saat ini dana yang dipakai untuk membayar SPP dari tiap siswa diambil dari donasi yang diberikan oleh donatur. Saat ini donatur pada Yayasan Anak pelangi Indonesia (API) ada dua yaitu donatur tetap dan donatur tidak tetap sehingga dana yang ada tidak pasti dan pernah terjadi kekurangan dana (dana tidak mencukupi untuk membayar beasiswa setiap siswa).

Contoh yang terjadi adalah dana (Jumlah Donasi) yang ada pada Yayasan Anak Pelangi Indonesia saat ini adalah Rp 4.000.000. Tabel 5 menunjukan bahwa terdapat 27 siswa yang akan dibayarkan dengan total Rp 3.930.000 sehingga masih ada 10 siswa yang beasiswanya belum dapat dibayarkan.

\section{Analisis Sistem}

Sistem ini menggunakan metode Weighted Product untuk mendukung keputusan dalam memilih siswa yang dibayarkan terlebih dahulu SPP-nya jika donasi yang diterima kurang dari total biaya yang dibutuhkan untuk membayarkan keseluruhan biaya SPP dari semua siswa. Sistem ini juga menyimpan data siswa, donatur, dan sekolah dimana siswa menempuh pendidikan. Data siswa dengan kriteria diolah dengan metode Weighted Product sehingga menghasilkan kesimpulan berupa alternatif siswa yang memiliki nilai tertinggi sampai terendah. Alternatif yang memiliki nilai tertinggi adalah alternatif yang cocok untuk dibayarkan terlebih dahulu. Berdasarkan urutan yang diperoleh maka akan disesuaikan dengan jumlah bayar dari masingmasing siswa dengan donasi yang tersedia.

Sistem ini digunakan oleh bagian administrasi dari Yayasan Anak Pelangi yang bertugas melakukan administrasi penerimaan dari donator dan melakukan pembayaran SPP.

Entity Relationship Diagram (ERD) menggambarkan logic dari entitas-entitas yang terlibat dalam dan hubungan antar entitas (Powell,
Gavin 2006). ERD SPK pembayaran beasiswa terdiri dari 4 entitas yaitu: siswa, donatur, sekolah, dan kriteria terdapat pada Gambar 1.

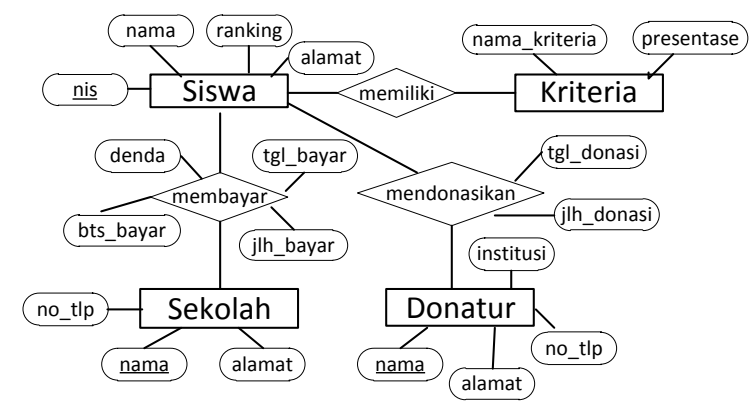

Gambar 1. ERD SPK Pembayaran Beasiswa

Use case dibuat dengan menjabarkan siapa saja aktor yang akan menggunakan aplikasi serta apa saja kegiatan yang bisa dilakukan oleh aktor tersebut pada aplikasi ini (Mathiassen et. al 2000). Use case diagram SPK pembayaran beasiswa ini terdapat pada Gambar 2.

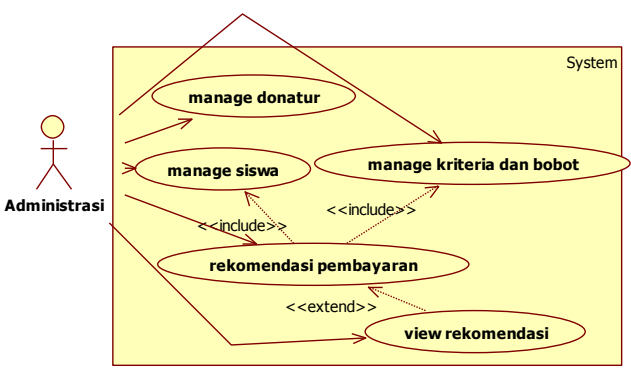

Gambar 2. Use case diagram SPK Pembayaran Beasiswa

\section{Kesimpulan}

Hasil yang diperoleh dari analisis terhadap SPK pembayaran beasiswa adalah:

a. Sistem yang dibangun melibatkan 4 kriteria yang menjadi acuan dalam proses pembayaran beasiswa. yaitu selisih tanggal bayar, jumlah bayar, denda dan prestasi dan diberi bobot $25 \%$ untuk masing-masing kriteria.

b. Hasil perhitungan menggunakan metode Weighted Product (WP) menggunakan nilai terbesar sebagai rekomendasi untuk menentukan siswa yang mendapat prioritas dalam pembayaran SPP.

c. Sistem dapat memberikan laporan tentang data donatur saat ini serta berapa jumlah donasi yang diberikan, laporan tentang siapa saja siswa yang akan dibayar sesuai dengan jumlah dana yang ada pada Yayasan dan 
laporan siswa-siswa yang belum dibayar dalam pembayaran SPP.

\section{Referensi}

Indrajit, 2001, Analisis dan Perancangan Sistem Berorientasi Objek, Bandung.

Kusumadewi, Sri et al. 2006, Fuzzy Multi Attribute Decision Making (Fuzzy MADM),
Yogyakarta: Graha Ilmu.

Mathiassen, et al. Al 2000, Object Oriented Analysis and Design, Danish: Marko.

Powell, Gavin, 2006, Beginning Database Design, Indianapolis: Wiley Publishing. 